\title{
PENGARUH KEPRIBADIAN, LINGKUNGAN, DAN DEMOGRAFIS TERHADAP KEINGINAN DAN PERILAKU MENJADI ENTREPRENEUR DI KALANGAN MAHASISWA
}

\author{
Mahyarni \\ Universitas Islam Negeri Sultan Syarif Kasim Riau \\ Email:mahyarni@uin-suska.sac.id \\ Astuti Meflinda \\ Universitas Islam Negeri Sultan Syarif Kasim Riau \\ Email: astoetimeflinda@yahoo.com
}

\begin{abstract}
Abstrak
Disadari semakin pentingnya peran entrepreneurship dalam pembangunan di negara-negara sedang berkembang, maka pemerintah dan instansi terkait mendorong semua pihak untuk menumbuhkan keinginan dan perilaku menjadi entrepreneur dikalangan generasi muda khususnya mahasiswa. Penelitian ini dilakukan pada Universitas Negeri di Provinsi Riau dengan tujuan untuk menguji dan menganalisis variabel kepribadian, lingkungan, dan demografis terhadap keinginan menjadi entrepreneur serta untuk menguji dan menganalisis pengaruh variabel keinginan terhadap perilaku untuk menjadi wirausaha di kalangan mahasiswa. Populasi dalam penelitian ini adalah seluruh mahasiswa Program strata satu yang terdaftar di Perguruan Tinggi tersebut dengan teknik pengambilan sampel adalah purposive sampling. Analisis data digunakan metode kuantitatif dengan menggunakan Partial Least Square (PLS). Hasil penelitian menunjukkan bahwa pengaruh variabel kepribadian dan lingkungan terhadap variabel keinginan untuk menjadi entrepreneur adalah signifikan, demikian juga dengan pengaruh variabel keinginan terhadap perilaku menjadi entrepreneur adalah signifikan.
\end{abstract}

Kata kunci:

Entrepreneur, Keinginan, Perilaku

\begin{abstract}
Realizing the growing importance of the role of entrepreneurship in development in developing countries, the government and relevant agencies encourage all parties to foster the intention and behavior become entrepreneurs among the young generation, especially students. This research was conducted at the State University in Riau province in order to test and analyze the personality, environmental, and demographic variables toward intention to be an entrepreneur and to test and analyze the effect of behavior intention variables to become entrepreneurs among students. The population in this study were all students of undergraduate courses listed in the Higher Education with the sampling technique is purposive sampling. Analysis of the data used quantitative method by using Partial Least Square (PLS). The results showed that the effect of personality and environment variable toward the intention to become an entrepreneur is significant, and the influence of intention to become entrepreneur is significant as well.
\end{abstract}

Keywords:

Behavior, Entrepreneur, Intention 


\section{PENDAHULUAN}

Pembangunan ekonomi membutuhkan dukungan Sumber Daya Manusia (SDM). Dukungan SDM dalam proses pembangunan terlihat dari peran SDM di berbagai sektor ekonomi yang bertujuan untuk meningkatkan produktivitas. Namun dalam kenyataannya masih sedikit penduduk yang tertarik untuk terlibat aktif secara langsung dalam berbagai sektor ekonomi terutama lulusan perguruan tinggi. Berdasarkan data dari Ditjen Dikti tahun 2011, menyatakan peminat kewirausahaan bagi lulusan perguruan tinggi masih sangat rendah, yakni sebesar $6,14 \%$ dari jumlah lulusan. Angka ini lebih rendah dari peminat wirausaha dari lulusan SMA yang mencapai angka 22,63\%. Sedangkan data tahun 2011, menyatakan jumlah wirausahawan di Indonesia baru mencapai 1,65 persen dari total penduduk Indonesia, Indonesia hanya memiliki 3.707.205 orang wirausahawan yang seharusnya 4,75 juta orang. Sedangkan McClelland Sosiolog Harvard juga menyatakan hal yang senada suatu negara dapat mencapai kemakmuran jika $2 \%$ dari jumlah penduduknya menjadi entrepreneur. (news.detik.com). Begitu juga menurut Osborne yang menyatakan suatu negara menjadi makmur apabila sedikitnya mempunyai $2 \%$ entrepreneur. Hasil riset yang dilakukan oleh Global Entrepreneurship Monitor juga menunjukkan sepertiga pertumbuhan ekonomi dihasilkan melalui kegiatan entrepreneur atau dikenal juga dengan istilah wirausaha. (http://www.gemconsortium.org). Ada kecenderungan di kalangan generasi muda pencari kerja, terutama bagi mereka yang memperoleh pendidikan di Perguruan Tinggi untuk mencari kerja di sektor formal. Hal ini menandakan bahwa generasi muda pencari kerja masih belum memiliki niat yang positif terhadap pekerjaan di sektor swasta, sehingga membawa 
dampak terhadap semakin meningkatnya jumlah angka pencari kerja yang tak tertampung, akhirnya mereka lebih baik menganggur daripada bekerja di sektor swasta. (Budhyani,2003).

Sikap dan Perilaku sangat dipengaruhi oleh sifat dan watak yang dimiliki oleh seseorang. Sifat dan watak yang baik, berorientasi pada kemajuan dan berpikir positif, merupakan sifat dan watak yang dibutuhkan oleh seorang wirausahawan agar wirausahawan tersebut dapat maju. Zimmerer dan Scarborough (1996; 6-7) mengemukakan delapan karakteristik yang meliputi : (1). Memiliki rasa tanggung jawab atas usaha-usaha yang dilakukannya, (2) Lebih memilih risiko yang moderat, (3) Percaya akan kemampuan dirinya untuk berhasil, (4) Selalu menghendaki umpan balik yang segera, (5) Berorientasi ke masa depan, perspektif, dan berwawasan jauh ke depan, (6) Memiliki semangat kerja dan kerja keras untuk mewujudkan keinginannya demi masa depan yang lebih baik, (7) Memiliki keterampilan dalam mengorganisasikan sumber daya untuk menciptakan nilai tambah, (8) Selalu menilai prestasi dengan uang. Seseorang dengan keinginan untuk memulai usaha memiliki kesiapan dan kemajuan yang lebih baik dalam menjalankan usahanya dibandingkan seseorang tanpa keinginan untuk memulai usaha. Keinginan untuk menjadi entrepreneur didefinisikan sebagai proses pencarian informasi yang dapat digunakan untuk mencapai tujuan pembentukan suatu usaha (Katz dan Gartner, 1988).

Wirausaha adalah seorang pembuat keputusan yang membantu terbentuknya sistem ekonomi perusahaaan yang bebas. Karir entrepreneur dapat mendukung kesejahteraan masyarakat, dan menghasilkan imbalan finansial yang nyata. Wirausaha di berbagai industri membantu perekonomian dengan menyediakan pekerjaan dan 
memproduksi barang dan jasa bagi konsumen dalam negeri maupun di luar negeri.

Sikap dan Perilaku sangat dipengaruhi oleh sifat dan watak yang dimiliki oleh seseorang. Karakteristik dalam menilai keinginan untuk menjadi entrepreneur adalah:

- Faktor Kepribadian

Buchori (1982:92) mengungkapkan "kepribadian berarti integrasi dari seluruh sifat seseorang baik sifat-sifat yang dipelajarinya maupun sifat-sifat yang diwarisinya, yang menyebakan kesan yang khas, unik pada orang lain” Karakteristik ini dilihat dari:

- Kebutuhan akan prestasi, McClelland (1961, 1971) telah memperkenalkan konsep kebutuhan akan prestasi sebagai salah satu motif psikologis. Kebutuhan prestasi dapat diartikan sebagai suatu kesatuan watak yang memotivasi seseorang untuk menghadapi tantangan untuk mencapai kesuksesan dan keunggulan (Lee, 1997: 103).

- Efikasi Diri, Bandura (1977: 2) mendefinisikan efikasi diri sebagai kepercayaan seseorang atas kemampuan dirinya untuk menyelesaikan suatu pekerjaan. Atau dengan kata lain, kondisi motivasi seseorang yang lebih didasarkan pada apa yang mereka percaya daripada apa yang secara objektif benar. Persepsi pribadi seperti ini memegang peranan penting dalam pengembangan keinginan seseorang.

- Faktor Lingkungan, faktor lingkungan yang dipercaya mempengaruhi wirausaha yaitu akses kepada modal, informasi dan kualitas jaringan sosial yang dimiliki.

- Akses kepada modal, merupakan hambatan klasik terutama dalam memulai usaha-usaha baru, setidaknya terjadi di negara-negara berkembang dengan dukungan lembaga-lembaga 
penyedia keuangan yang tidak begitu kuat (Indarti, 2004).

- Ketersediaan informasi, merupakan faktor penting yang mendorong keinginan seseorang untuk membuka usaha baru (Indarti, 2004) dan faktor kritikal bagi pertumbuhan dan keberlangsungan usaha (Duh, 2003; Kristiansen, 2002b; Mead \& Liedholm, 1998; Swierczek dan Ha, 2003).

- Jaringan sosial, Mazzarol et al. (1999) menyebutkan bahwa jaringan sosial mempengaruhi keinginan entrepreneur. Jaringan sosial didefinisikan sebagai hubungan antara dua orang yang mencakup a) komunikasi atau penyampaian informasi dari satu pihak ke pihak lain; b) pertukaran barang dan jasa dari dua belah pihak; dan c) muatan normatif atau ekspektasi yang dimiliki oleh seseorang terhadap orang lain karena karakter-karakter atau atribut khusus yang ada.
- Faktor demografis, demografi diartikan sebagai tulisan atau gambaran tentang penduduk, terutama tentang kelahiran, perkawinan, kematian dan migrasi. Demografi meliputi studi ilmiah tentang jumlah, persebaran geografis, komposisi penduduk, serta bagaimana faktor faktor ini berubah dari waktu ke waktu Penelitian-penelitian terdahulu menunjukkan bahwa faktor-faktor demografis seperti jender, umur, pendidikan dan pengalaman bekerja seseorang berpengaruh terhadap keinginannya untuk menjadi seorang wirausaha (Mazzarol et al., 1999; Tkachev dan Kolvereid, 1999). Pengaruh gender atau jenis kelamin terhadap keinginan seseorang menjadi wirausaha telah banyak diteliti (Mazzarol et al., 1999; Kolvereid, 1996; Matthews dan Moser, 1996; Schiller dan Crewson, 1997). Hasil penelitian yang dilakukan oleh Sinha (1996) di India, menunjukkan bahwa hampir sebagian 
besar wirausaha yang sukses adalah mereka yang berusia relatif muda. Latar belakang pendidikan seseorang terutama yang terkait dengan bidang usaha, seperti bisnis dan manajemen atau ekonomi dipercaya akan mempengaruhi keinginan dan minatnya untuk memulai usaha baru di masa mendatang. Kolvereid (1996) menemukan bahwa seseorang yang memiliki pengalaman bekerja mempunyai keinginan entrepreneur yang lebih tinggi dibandingkan mereka yang tidak pernah bekerja sebelumnya.

Penelitian yang dilakukan sekarang berbeda dengan penelitian sebelumnya dalam hal variabel dan indikator yang digunakan. Adapun tambahan variabel yang digunakan adalah memasukkan variabel perilaku serta indikator dengan merujuk penelitian yang dilakukan Fishbein dan Ajzen (1975; Werner (2004), dengan asumsi individu rasional dalam mempertimbangkan tindakan mereka dan implikasi dari tindakan mereka (pengambilan keputusan). Penambahan variabel perilaku menjadi entrepreneur karena pada penelitian sebelumnya yang dilakukan oleh Indarti, 2004 belum diteliti. Sementara penelitian sekarang ini ingin mengembangkan model yang pernah diteliti oleh Chatzoglou dan Vraimaki (2009) yang melihat pengaruh kenginan terhadap perilaku. Disamping itu keinginan seseorang akan suatu objek harus diiringi dengan perilaku aktual terhadap objek tersebut. Adapun indikator yang digunakan disesuaikan dengan situasi dan kondisi yang terjadi.

Disadari demikian pentingnya peranan wirausaha dalam pembangunan di negara-negara sedang berkembang, maka hal ini mendorong semua pihak untuk menumbuhkan keinginan berwirausaha dikalangan generasi muda terutama mahasiswa dalam rangka membangun kemandirian mahasiswa setelah selesai menimba ilmu di perguruan tinggi, 
(Budhyani,2003). Pernyataan di atas didasarkan pada data Badan Pusat Statistik (BPS) yang mencatat bahwa jumlah pengangguran sarjana atau lulusan universitas pada Februari 2013 mencapai 360 ribu orang, atau $5,04 \%$ dari total pengangguran yang mencapai 7,2 juta orang. (BPS.go.id).

Penelitian yang terkait keinginan dan perilaku mahasiswa untuk menjadi entrepreneur ini dapat digunakan oleh perguruan tinggi sebagai penentu kebijakan dalam menjalin kerjasama dengan dunia usaha dalam bentuk melakukan pelatihan dan magang atau PKL di tempat tersebut. Sedangkan bagi pemerintah dapat digunakan untuk melihat problem ketenagakerjaan terkait dengan semakin meningkatnya angka pengangguran sementara lapangan kerja sangat terbatas. Dalam menyelesaikan masalah ini maka pemerintah perlu menentukan arah kebijakan dalam menciptakan iklim usaha yang kondusif dan membuka peluang usaha dengan mendorong anak muda untuk menjadi entrepreneur. Penelitian ini bertujuan untuk mengetahui pengaruh variabel kepribadian, lingkungan, dan demografis, terhadap keinginan menjadi entrepreneur serta untuk mengetahui pengaruh keinginan terhadap perilaku aktual untuk menjadi entrepreneur di kalangan mahasiswa.

\section{METODE PENELITIAN}

Penelitian ini dilakukan di Provinsi Riau yang merupakan salah satu provinsi di Indonesia yang langsung berbatasan dengan negara tetangga Malaysia. Provinsi Riau terletak di Jantung Pulau Sumatera dengan letak yang sangat strategis dan merupakan pusat perdagangan dan pendidikan. Populasi dalam penelitian ini adalah seluruh mahasiswa program strata 1 yang ada di Universitas Negeri di Provinsi Riau. Pengambilan sampel didasarkan pada 
judgement atau purposive sampling, sampel dipilih dengan adanya beberapa kriteria tertentu yang digunakan oleh peneliti (Remenyi, 2000). Sampel ditetapkan sebanyak 120 orang mahasiswa, dengan alasan pemilihan sampel adalah mahasiswa diharapkan setelah lulus dapat langsung membuka usaha dan menjadi entrepreneur.
Untuk keperluan analisis data maka dipergunakan metode analisis statistik inferensial dengan menggunakan SEM berbasis variance yang disebut dengan Partial Least Square (PLS).

Adapun hubungan antar variabel yang diteliti dapat diilustrasikan dalam sebuah model pada Gambar 1. berikut ini:

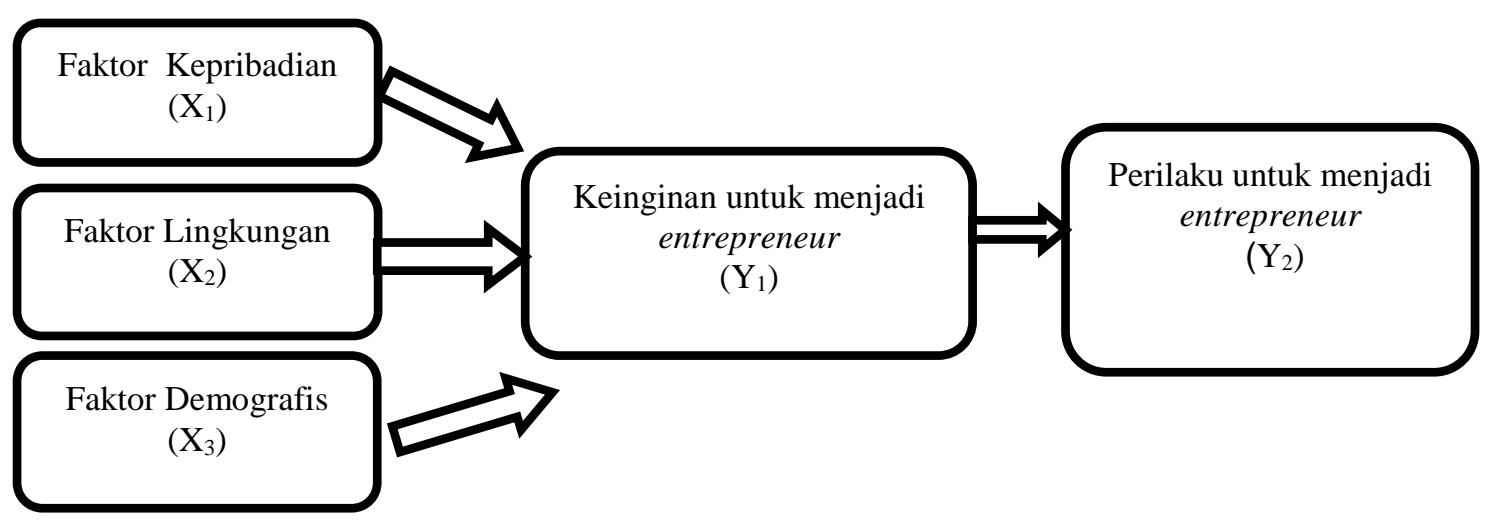

Gambar 1.

Model Struktural Penelitian

Buchori (1982:92) mengungkapkan "kepribadian berarti integrasi dari seluruh sifat seseorang baik sifat-sifat yang dipelajarinya maupun sifat-sifat yang diwarisinya, yang menyebabkan kesan yang khas, unik pada orang lain. H-1 menyatakan bahwa faktor kepribadian berpengaruh terhadap keinginan mahasiswa menjadi wirausaha. Selanjutnya faktor lingkungan, dipercaya mempengaruhi wirausaha yaitu akses mereka kepada modal, informasi dan kualitas jaringan sosial yang dimiliki, dengan H-2 adalah faktor lingkungan berpengaruh terhadap keinginan mahasiswa menjadi 
wirausaha. Penelitian-penelitian terdahulu menunjukkan bahwa faktor-faktor demografis seperti gender, umur, pendidikan dan pengalaman bekerja seseorang berpengaruh terhadap keinginannya untuk menjadi seorang wirausaha (Mazzarol et al., 1999; Tkachev dan Kolvereid, 1999) dengan H-3 faktor demografi berpengaruh terhadap keinginan mahasiswa menjadi wirausaha. Hipotesis berikutnya H-4 meneliti hubungan antara keinginan untuk terlibat dalam kegiatan entrepreneur dan perilaku yang sebenarnya dari entrepreneur, Perilaku didefinisikan sebagai tingkat keyakinan mahasiswa akan melakukan kegiatan entrepreneur. Ajzen (1991, 2002), Bock dan Kim (2000, 2002) maka H-4 mengusulkan hipotesis adanya keinginan mahasiswa untuk menjadi wirausaha akan menentukan perilaku menjadi wirausaha.

Dari hipotesis di atas, maka untuk mengetahui hubungan Keinginan dan Perilaku Menjadi Wirausaha di kalangan Mahasiswa maka diperlukan konsep operasional variabel yang dapat dilihat pada Tabel 1. di bawah ini:

Tabel 1.

Konsep Operasional Variabel Penelitian

\begin{tabular}{|c|c|c|}
\hline Variabel & Konsep Variabel & Indikator \\
\hline $\begin{array}{l}\text { Faktor Kepribadian } \\
\qquad\left(\mathrm{X}_{1}\right)\end{array}$ & $\begin{array}{l}\text { Kepribadian berarti integrasi dari } \\
\text { seluruh sifat seseorang baik sifat- } \\
\text { sifat yang dipelajarinya maupun } \\
\text { sifat-sifat yang diwarisinya, yang } \\
\text { menyebabkan kesan yang khas, } \\
\text { unik pada orang lain, } \\
\text { (Buchori,1982) }\end{array}$ & $\begin{array}{l}\text { 1. Motivasi untuk berprestasi } \\
\text { 2. Untuk mendapatkan konsumen } \\
\text { yang banyak } \\
\text { 3. Mengembangkan ide baru } \\
\text { 4. Efikasi diri }\end{array}$ \\
\hline $\begin{array}{l}\text { Faktor Lingkungan } \\
\qquad\left(\mathrm{X}_{2}\right)\end{array}$ & $\begin{array}{l}\text { Faktor lingkungan yang dipercaya } \\
\text { mempengaruhi wirausaha yaitu } \\
\text { akses mereka kepada modal, } \\
\text { informasi dan kualitas jaringan } \\
\text { sosial yang dimiliki (Indarti, 2004) }\end{array}$ & $\begin{array}{l}\text { 1. Kemudahan memperoleh modal } \\
\text { 2. Perbankan memberikan layanan } \\
\text { yang sama } \\
\text { 3. Ketersediaan informasi tentang } \\
\text { UMKM } \\
\text { 4. Mempunyai hubungan kerjasama } \\
\text { yang baik } \\
\text { 5. Menjalin kerjasama dengan } \\
\text { instansi tertentu }\end{array}$ \\
\hline
\end{tabular}




\begin{tabular}{|c|c|c|}
\hline Variabel & Konsep Variabel & Indikator \\
\hline $\begin{array}{l}\text { Faktor Demografis } \\
\left(\mathrm{X}_{3}\right)\end{array}$ & $\begin{array}{l}\text { Faktor-faktor demografis seperti } \\
\text { jender, umur, pendidikan dan } \\
\text { pengalaman bekerja seseorang } \\
\text { berpengaruh terhadap keinginannya } \\
\text { untuk menjadi seorang wirausaha } \\
\text { (Mazzarol et al., 1999; Tkachev dan } \\
\text { Kolvereid, 1999). }\end{array}$ & $\begin{array}{ll}\text { 1. } & \text { Umur } \\
\text { 2. } & \text { Jenis kelamin } \\
\text { 3. } & \text { Semester } \\
\text { 4. } & \text { Pengalaman kerja }\end{array}$ \\
\hline $\begin{array}{l}\text { Keinginan } \\
\text { Untuk menjadi } \\
\text { entrepreneur } \\
\left(\mathrm{Y}_{1}\right)\end{array}$ & $\begin{array}{l}\text { Keinginan untuk menjadi } \\
\text { entrepreneur didefinisikan sebagai } \\
\text { proses pencarian informasi yang } \\
\text { dapat digunakan untuk mencapai } \\
\text { tujuan pembentukan suatu usaha } \\
\text { (Katz dan Gartner, 1988) }\end{array}$ & $\begin{array}{l}\text { 1. Wirausaha lebih diperlukan pada } \\
\text { masa depan } \\
\text { 2. Menjadi wirausaha membuat } \\
\text { perekonomian lebih efisien } \\
\text { 3. Menjadi wirausaha akan membantu } \\
\text { pemerintah } \\
\text { 4. Menjadi wirausaha merupakan } \\
\text { keinginan sendiri sejak dulu }\end{array}$ \\
\hline $\begin{array}{c}\text { Perilaku untuk } \\
\text { menjadi entrepreneur } \\
\left(\mathrm{Y}_{2}\right)\end{array}$ & $\begin{array}{l}\text { Perilaku didefinisikan sebagai } \\
\text { tingkat keyakinan mahasiswa akan } \\
\text { melakukan kegiatan entrepreneur. } \\
\text { Ajzen }(1991,2002) \text {, Bock dan Kim } \\
(2000,2002)\end{array}$ & $\begin{array}{l}\text { 1. Pertumbuhan ekonomi yang } \\
\text { meningkat } \\
\text { 2. Petunjuk dan pedoman dalam } \\
\text { melakukan entrepreneur } \\
\text { 3. Tahu bagaimana melakukan } \\
\text { kegiatan entrepreneur } \\
\text { 4. Tahu dengan siapa harus melakukan } \\
\text { kegiatan entrepreneur } \\
\text { 5. Hidup lebih disiplin } \\
\text { 6. Hemat }\end{array}$ \\
\hline
\end{tabular}

Sumber : Data olahan

III. HASIL DAN PEMBAHASAN

\subsection{Hasil}

Dari hipotesis yang telah
Berdasarkan out put dari PLS maka dihasilkan model sebagai berikut (Gambar

\section{2.):}

2.):

dikemukakan maka dilakukan langkah-

langkah penyelesaian dengan menggunakan

Program PLS sebagai berikut:

\section{Model Pengukuran (Outer Model)}

2.Model Struktural (Inner Model) 


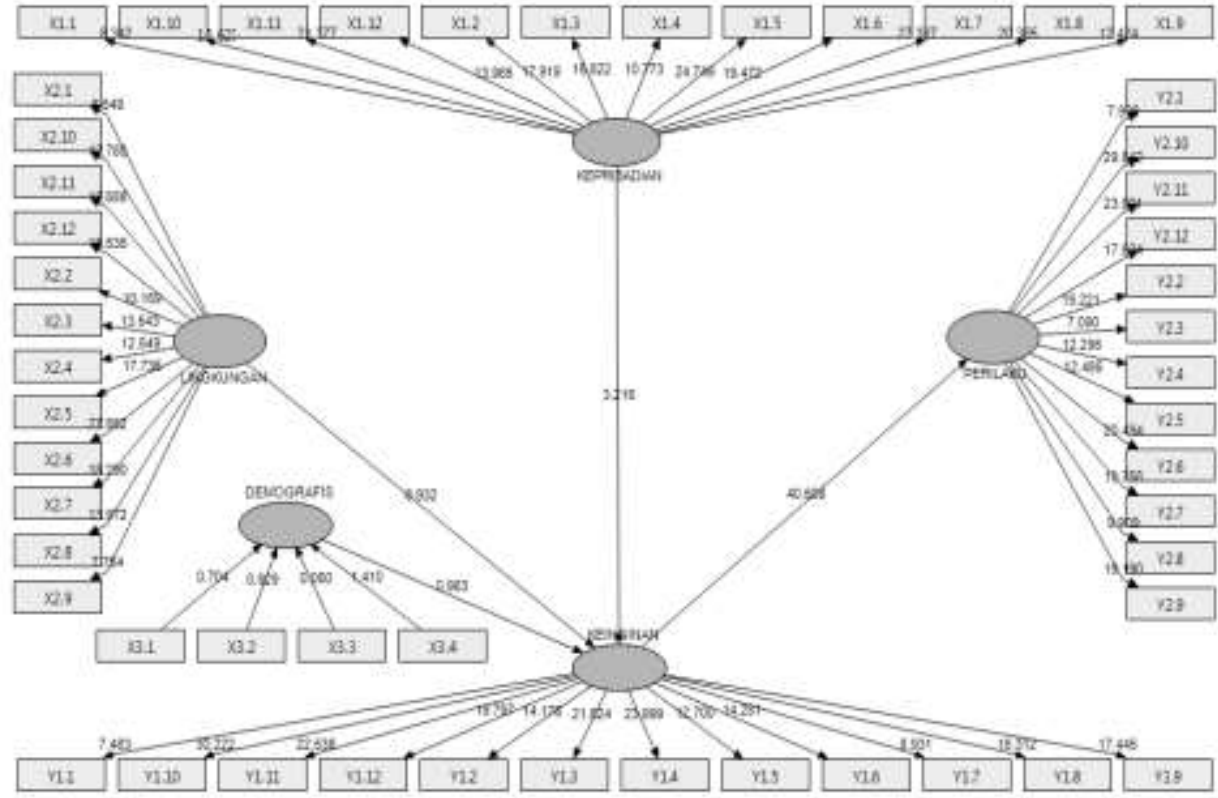

Gambar 2.

Model Output PLS

Sedangkan hasil interpretasi data

dari output PLS di atas adalah pada Tabel 2.

berikut ini:

Tabel 2.

Path Coefficients Antar Variabel yang Diteliti

\begin{tabular}{|l||c||c||}
\hline \hline \multicolumn{1}{|c|}{ Variabel } & Original Sample $(\boldsymbol{O})$ & T Statistics $($ O/STERR|) \\
\hline \hline KEPRIBADIAN -> KEINGINAN & 0.235498 & 3.216361 \\
\hline \hline LINGKUNGAN -> KEINGINAN & 0.691843 & 8.931551 \\
\hline \hline DEMOGRAFIS -> KEINGINAN & 0.102868 & 0.963152 \\
\hline \hline KEINGINAN -> PERILAKU & 0.856158 & 40.508246 \\
\hline \hline
\end{tabular}

Sumber : Data olahan

Dari Gambar 2. dan Tabel 2. di atas maka dapat diketahui hasil pengujian model struktural dengan melihat pengaruh antar variabel berikut ini: 
- Pengaruh variabel kepribadian terhadap variabel keinginan untuk menjadi wirausaha.

Dari tabel diatas diketahui bahwa nilai $\mathrm{t}$ hitung (statistik) sebesar 3.216361 lebih besar dari $\mathrm{t}$ tabel sebesar 1.96. berarti bahwa terdapat pengaruh yang signifikan antara variabel kepribadian terhadap variabel keinginan untuk menjadi wirausaha dengan kata lain faktor kepribadian mendorong meningkatnya keinginan untuk menjadi wirausaha.

- Pengaruh variabel lingkungan terhadap variabel keinginan untuk menjadi wirausaha.

Dari tabel diatas diketahui bahwa nilai $\mathrm{t}$ hitung (statistik) sebesar 8.931551 lebih besar dari $\mathrm{t}$ tabel sebesar 1.96. berarti bahwa terdapat pengaruh yang signifikan antara variabel lingkungan terhadap variabel keinginan untuk menjadi wirausaha dengan kata lain faktor lingkungan mendorong meningkatnya keinginan untuk menjadi wirausaha.

- Pengaruh variabel demografis terhadap variabel keinginan untuk menjadi wirausaha.

Dari tabel diatas diketahui bahwa nilai $\mathrm{t}$ hitung (statistik) sebesar 0.963152 lebih kecil dari $\mathrm{t}$ tabel sebesar 1.96. berarti bahwa terdapat pengaruh yang tidak signifikan antara variabel demografis terhadap variabel keinginan untuk menjadi wirausaha dengan kata lain faktor demografis tidak mendorong meningkatnya keinginan untuk menjadi wirausaha.

- Pengaruh variabel keinginan untuk menjadi wirausaha terhadap variabel perilaku menjadi wirausaha.

Dari tabel diatas diketahui bahwa nilai $\mathrm{t}$ hitung (statistik) sebesar 40.508246 lebih besar dari $\mathrm{t}$ tabel sebesar 1.96. berarti bahwa terdapat pengaruh yang signifikan antara variabel keinginan terhadap variabel 
perilaku untuk menjadi wirausaha dengan kata lain variabel keinginan mendorong meningkatnya perilaku untuk menjadi wirausaha.

\subsection{Pembahasan}

Pembahasan tentang hipotesis yang diperoleh dari pengaruh langsung maupun pengaruh tidak langsung adalah sebagai berikut:

\subsubsection{Pengaruh langsung variabel kepribadian terhadap variabel keinginan untuk menjadi wirausaha}

Pengujian hipotesis pengaruh langsung antara variabel kepribadian terhadap variabel keinginan untuk menjadi wirausaha diperoleh hasil terdapat pengaruh yang signifikan antara variabel kepribadian terhadap variabel keinginan untuk menjadi wirausaha. Buchori mengungkapkan "kepribadian berarti integrasi dari seluruh sifat seseorang baik sifat-sifat yang dipelajarinya maupun sifatsifat yang diwarisinya, yang menyebabkan kesan yang khas, unik pada orang lain. Indikator yang dipakai untuk variabel kepribadian adalah motivasi untuk berprestasi, untuk mendapatkan konsumen yang banyak, mengembangkan ide baru dan efikasi diri.

McClelland (1961, 1971) telah memperkenalkan konsep kebutuhan akan prestasi sebagai salah satu motif psikologis. Kebutuhan akan prestasi dapat diartikan sebagai suatu kesatuan watak yang memotivasi seseorang untuk menghadapi tantangan untuk mencapai kesuksesan dan keunggulan (Lee, 1997: 103). Lebih lanjut, McClelland (1976) menegaskan bahwa kebutuhan akan prestasi sebagai salah satu karakteristik kepribadian seseorang yang akan mendorong seseorang untuk memiliki keinginan menjadi wirausaha. Menurutnya, ada tiga atribut yang melekat pada seseorang 
yang mempunyai kebutuhan akan prestasi yang tinggi, yaitu (a) menyukai tanggung jawab pribadi dalam mengambil keputusan, (b) mau mengambil resiko sesuai dengan kemampuannya, dan (c) memiliki minat untuk selalu belajar dari keputusan yang telah diambil. Hasil penelitian dari Scapinello (1989) menunjukkan bahwa seseorang dengan tingkat kebutuhan akan prestasi yang tinggi kurang dapat menerima kegagalan daripada mereka dengan kebutuhan akan prestasi rendah. Dengan kata lain, kebutuhan akan prestasi berpengaruh pada atribut kesuksesan dan kegagalan. Sejalan dengan hal tersebut, Sengupta dan Debnath (1994) dalam penelitiannya di India menemukan bahwa kebutuhan akan prestasi berpengaruh besar dalam tingkat kesuksesan seorang wirausaha. Lebih spesifik, kebutuhan akan prestasi juga dapat mendorong kemampuan pengambilan keputusan dan kecenderungan untuk mengambil resiko seorang wirausaha.
Semakin tinggi kebutuhan akan prestasi seorang wirausaha, semakin banyak keputusan tepat yang akan diambil. Wirausaha dengan kebutuhan akan prestasi tinggi adalah pengambil resiko dan menyukai hal-hal yang keuntungan dan manfaat yang tepat dan cepat.

Dalam penelitian ini juga memasukkan dua indikator yang berkaitan dengan upaya mendapatkan konsumen yang banyak dan mengembangkan ide baru, kedua indikator ini merupakan orientasi mahasiswa untuk membentuk pribadi yang mandiri, kreatif dan inovatif yang berguna untuk mengembangkan kegiatan usaha pada masa datang.

$$
\text { Sedangkan Bandura (1977: 2) }
$$

mendefinisikan efikasi diri sebagai kepercayaan seseorang atas kemampuan dirinya untuk menyelesaikan suatu pekerjaan. Atau dengan kata lain, kondisi motivasi seseorang yang lebih didasarkan pada apa yang mereka percaya daripada apa 
yang secara objektif benar. Persepsi pribadi seperti ini memegang peranan penting dalam pengembangan keinginan seseorang. Senada dengan hal tersebut, Cromie (2000) menjelaskan bahwa efikasi diri mempengaruhi kepercayaan seseorang pada tercapai atau tidaknya tujuan yang sudah ditetapkan. Disisi lain, banyak peneliti percaya bahwa efikasi diri terkait erat dengan pengembangan karir. Merujuk Betz dan Hacket (1986), efikasi diri akan karir seseorang adalah domain yang menggambarkan pendapat pribadi seseorang dalam hubungannya dengan proses pemilihan dan penyesuaian karir. Dengan demikian, efikasi diri akan karir seseorang dapat menjadi faktor penting dalam penentuan apakah keinginan entrepreneur seseorang sudah terbentuk pada tahapan awal seseorang memulai karirnya. Lebih lanjut, Betz dan Hacket menyatakan bahwa semakin tinggi tingkat efikasi diri seseorang pada entrepreneur di masa-masa awal seseorang dalam berkarir, semakin kuat keinginan entrepreneur yang dimilikinya. Selain itu, Gilles dan Rea (1999) membuktikan pentingnya efikasi diri dalam proses pengambilan keputusan terkait dengan karir seseorang. Efikasi diri terbukti signifikan menjadi penentu keinginan seseorang.

Hasil penelitian ini sesuai dengan temuan penelitian yang membuktikan bahwa faktor kepribadian seperti kebutuhan akan prestasi (McClelland, 1961; Sengupta dan Debnath, 1994) dan efikasi diri (Gilles dan Rea, 1999; Indarti, 2004) merupakan prediktor signifikan menentukan keinginan menjadi wirausaha atau dengan kata lain bermakna semakin baik tingkat kepribadian mahasiswa maka semakin tinggi pula keinginan untuk menjadi wirausaha. 


\subsubsection{Pengaruh langsung variabel \\ lingkungan terhadap variabel \\ keinginan untuk menjadi \\ wirausaha}

Pengujian hipotesis pengaruh langsung antara variabel lingkungan terhadap variabel keinginan untuk menjadi wirausaha diperoleh hasil terdapat pengaruh yang signifikan antara variabel lingkungan terhadap variabel keinginan untuk menjadi wirausaha. Adapun indikator yang dipakai dalam membentuk variabel lingkungan adalah akses kepada modal, ketersediaan informasi, jaringan sosial.

Akses kepada modal merupakan hambatan klasik terutama dalam memulai usaha-usaha baru, setidaknya terjadi di negara-negara berkembang dengan dukungan lembaga-lembaga penyedia keuangan yang tidak begitu kuat (Indarti, 2004). Studi empiris terdahulu menyebutkan bahwa kesulitan dalam mendapatkan akses modal, kredit dan kendala sistem keuangan dipandang sebagai hambatan utama dalam kesuksesan usaha menurut calon-calon wirausaha di negara-negara berkembang (Marsden, 1992; Meier dan Pilgrim, 1994; Steel, 1994). Di negara-negara maju di mana infrastruktur keuangan sangat efisien, akses kepada modal juga dipersepsikan sebagai hambatan untuk menjadi pilihan wirausaha karena tingginya hambatan masuk untuk mendapatkan modal yang besar terhadap rasio tenaga kerja di banyak industri yang ada. Penelitian relatif baru menyebutkan bahwa akses kepada modal menjadi salah satu penentu kesuksesan suatu usaha (Kristiansen et al., 2003; Indarti, 2004).

Ketersediaan informasi usaha merupakan faktor penting yang mendorong keinginan seseorang untuk membuka usaha baru (Indarti, 2004) dan faktor kritikal bagi pertumbuhan dan keberlangsungan usaha (Duh, 2003; Kristiansen, 2002b; Mead \& Liedholm, 1998; Swierczek dan Ha, 2003). Penelitian yang dilakukan oleh Singh dan 
Krishna (1994) di India membuktikan bahwa keinginan yang kuat untuk memperoleh informasi adalah salah satu karakter utama seorang wirausaha. Pencarian informasi mengacu pada frekuensi kontak yang dibuat oleh seseorang dengan berbagai sumber informasi. Hasil dari aktivitas tersebut sering tergantung pada ketersediaan informasi, baik melalui usaha sendiri atau sebagai bagian dari sumber daya sosial dan jaringan. Ketersediaan informasi baru tergantung pada karakteristik seseorang, seperti tingkat pendidikan dan kualitas infrastruktur, meliputi cakupan media dan sistem telekomunikasi (Kristiansen, 2002b).

Mazzarol et al. (1999) menyebutkan bahwa jaringan sosial mempengaruhi keinginan entrepreneur. Jaringan sosial didefinisikan sebagai hubungan antara dua orang yang mencakup a) komunikasi atau penyampaian informasi dari satu pihak ke pihak lain; b) pertukaran barang dan jasa dari dua belah pihak; dan c) muatan normatif atau ekspektasi yang dimiliki oleh seseorang terhadap orang lain karena karakter-karakter atau atribut khusus yang ada. Bagi wirausaha, jaringan merupakan alat mengurangi resiko dan biaya transaksi serta memperbaiki akses terhadap ide-ide bisnis, informasi dan modal (Aldrich dan Zimmer, 1986). Hal senada diungkapkan oleh Kristiansen (2003) yang menjelaskan bahwa jaringan sosial terdiri dari hubungan formal dan informal antara pelaku utama dan pendukung dalam satu lingkaran terkait dan menggambarkan jalur bagi wirausaha untuk mendapatkan akses kepada sumber daya yang diperlukan dalam pendirian, perkembangan dan kesuksesan usaha.

Hasil penelitian ini sesuai dengan temuan penelitian terdahulu yang dilakukan oleh Kristiansen (2001;2002) menyebut bahwa faktor lingkungan seperti hubungan sosial, infrastruktur fisik dan institusional dapat mempengaruhi keinginan menjadi wirausaha atau dengan kata lain semakin 
bagus tingkat penguasaan terhadap pengalaman bekerja seseorang lingkungan akan semakin tinggi pula diperhitungkan sebagai penentu bagi keinginan untuk menjadi wirausaha.

keinginan menjadi wirausaha. Penelitian ini dilakukan di India yang menemukan bahwa $\begin{array}{ccccc}\text { 3.2.3 } & \text { Pengaruh } & \text { langsung } & \text { variabel } & \text { latar belakang pendidikan seseorang } \\ & \text { demografis } & \text { terhadap } & \text { variabel } & \text { menentukan tingkat keinginan seseorang dan } \\ \text { keinginan } & \text { untuk } & \text { menjadi } & \text { kesuksesan suatu bisnis yang dijalankan atau }\end{array}$ wirausaha dengan kata lain faktor demografis Pengujian hipotesis pengaruh mendorong keinginan menjadi wirausaha.

langsung antara variabel demografis Perbedaan hasil antara penelitian terhadap variabel keinginan untuk menjadi wirausaha diperoleh hasil terdapat pengaruh yang tidak signifikan antara variabel demorafis terhadap variabel keinginan untuk menjadi wirausaha. Pada penelitian ini indikator yang dipakai untuk variabel demografis adalah umur, jenis kelamin, semester, dan pengalaman kerja.

Hasil penelitian ini tidak sejalan dengan temuan penelitian terdahulu yang dilakukan oleh Sinha, 1996, yang menyatakan faktor demografi seperti umur, jenis kelamin, latar belakang pendidikan dan 
berbakat dan semua orang bisa melakukannya. Entrepreneur telah menjadi suatu disiplin ilmu yang mempelajari tentang nilai, kemampuan (ability) dan perilaku seseorang dalam menghadapi tantangan hidup untuk memperoleh peluang dengan berbagai resiko yang mungkin dihadapinya. Dari pendapat di atas bermakna siapa saja bisa menjadi seorang wirausaha, tidak harus didasarkan pada faktor demografis seperti umur, jenis kelamin, semester, dan pengalaman kerja. Hal yang terpenting disini adalah adanya kemauan untuk menjadi wirausaha dan pembelajaran tentang entrepreneur sudah harus kita berikan kepada generasi muda sejak usia dini.

\subsubsection{Pengaruh langsung variabel keinginan untuk menjadi wirausaha terhadap variabel perilaku menjadi wirausaha}

Pengujian hipotesis pengaruh langsung antara variabel keinginan terhadap variabel perilaku untuk menjadi wirausaha diperoleh hasil terdapat pengaruh yang signifikan antara variabel keinginan terhadap variabel perilaku untuk menjadi wirausaha Adapun indikator yang dipakai pada penelitian ini untuk variabel keinginan adalah wirausaha lebih diperlukan pada masa depan, menjadi wirausaha membuat perekonomian lebih efisien, menjadi wirausaha akan membantu pemerintah, menjadi wirausaha merupakan keinginan sendiri sejak dulu.

Hasil penelitian ini sesuai dengan temuan penelitian terdahulu yang menyatakan semakin tinggi keinginan menjadi wirausaha maka semakin tinggi pula perilaku untuk menjadi wirausaha. Keinginan menjadi wirausaha dapat diartikan sebagai proses pencarian informasi yang dapat digunakan untuk mencapai tujuan pembentukan suatu usaha (Katz dan Gartner, 1988), sedangkan perilaku menjadi entrepreneur dalam penelitian ini 
didefinisikan sebagai tingkat keyakinan mahasiswa akan melakukan kegiatan entrepreneur. Ajzen (1991, 2002); Bock dan $\operatorname{Kim}$ (2000, 2002). Seseorang dengan keinginan untuk memulai usaha akan memiliki kesiapan dan kemajuan yang lebih baik dalam usaha yang dijalankan dibandingkan seseorang tanpa keinginan untuk memulai usaha, seperti yang dinyatakan oleh Krueger dan Carsrud (1993), keinginan telah terbukti menjadi prediktor yang terbaik bagi perilaku entrepreneur. Oleh karena itu, keinginan dapat dijadikan sebagai pendekatan dasar yang masuk akal untuk memahami siapa-siapa yang akan menjadi wirausaha (Choo dan Wong, 2006).

Untuk menumbuhkembangkan jiwa entrepreneur dan meningkatkan aktivitas entrepreneur agar para lulusan perguruan tinggi lebih menjadi pencipta lapangan kerja dari pada pencari kerja, maka diperlukan suatu usaha nyata. Berwirausaha merupakan pilihan yang tepat dan logis, sebab selain peluang lebih besar untuk berhasil, hal ini sesuai dengan program pemerintah dalam percepatan penciptaan pengusaha kecil dan menengah yang kuat dan bertumpu pada ilmu pengetahuan dan teknologi (Indarti dan Rostiani, 2008).

Penelitian ini telah dilakukan dengan mengacu pada kaedah-kaedah ilmiah, namun penelitian ini masih memiliki keterbatasan sebagai berikut: penelitian ini terbatas hanya mengukur pengaruh variabel kepribadian, lingkungan dan demografis terhadap keinginan dan perilaku menjadi entrepreneur. Hasil penelitian ini tidak bisa digeneralisasi untuk seluruh universitas di tanah air karena masih sedikitnya jumlah sampel yang diteliti dan perlu pertimbangan untuk penelitian yang akan datang menambah variabel lain yang berkaitan dengan perilaku dan keinginan menjadi entrepreneur seperti agama dan budaya. 


\section{KESIMPULAN DAN SARAN}

Dari hasil penelitian dan pembahasan, maka kesimpulan yang dapat diambil sebagai berikut:

- Pengujian hipotesis pengaruh langsung antara variabel kepribadian terhadap variabel keinginan untuk menjadi wirausaha diperoleh hasil terdapat pengaruh yang signifikan antara variabel kepribadian terhadap variabel keinginan untuk menjadi wirausaha.

- Pengujian hipotesis pengaruh langsung antara variabel lingkungan terhadap variabel keinginan untuk menjadi wirausaha diperoleh hasil terdapat pengaruh yang signifikan antara variabel lingkungan terhadap variabel keinginan untuk menjadi wirausaha.

- Pengujian hipotesis pengaruh langsung antara variabel demografis terhadap variabel keinginan untuk menjadi wirausaha diperoleh hasil terdapat pengaruh yang tidak signifikan antara variabel demorafis terhadap variabel keinginan untuk menjadi wirausaha.

- Pengujian hipotesis pengaruh langsung antara variabel keinginan terhadap variabel perilaku untuk menjadi wirausaha diperoleh hasil terdapat pengaruh yang signifikan antara variabel keinginan terhadap variabel perilaku untuk menjadi wirausaha.

Dari hasil penelitian dan pembahasan, maka saran yang dapat dikemukakan adalah sebagai berikut:

- Bagi pemerintah daerah penelitian ini diharapkan:

- Hasil penelitian ini dapat membantu pemerintah menentukan kebijakan tentang entrepreneur yang berkaitan dengan perlu dilakukan pelatihan secara rutin di kalangan mahasiswa tentang kewirausahaan, kepemimpinan, marketing online, perbankan dan kepariwisataan dan khusus untuk 
kalangan anak-anak muda yang putus sekolah dilanjutkan pelatihan tentang Kejuruan Informasi dan Teknologi dengan konsentrasi Multi Media dan Design Grafis, Kejuruan Otomotif konsentrasi mobil bensin dan sepeda motor, Kejuruan Aneka Kejuruan dengan konsentrasi menjahit dan bordir serta Kejuruan Listrik dan Elektronik dengan konsentrasi Jurusan teknik pendingin (AC, kulkas dan mobil).

- Hasil penelitian ini dapat memperbaiki iklim usaha dengan adanya perhatian pemerintah yang lebih besar terhadap UMKM, sehingga menarik minat mahasiswa untuk menjadi entrepreneur.

- Bagi Pimpinan Universitas penelitian ini bisa digunakan untuk menjalin kerjasama dengan instansi terkait dengan melakukan berbagai kegiatan pelatihan yang diminati oleh mahasiswa dan berpeluang untuk membuka usaha secara mandiri. 


\section{DAFTAR PUSTAKA}

Ajzen, I .2002, "Constructing a TPB questionnaire: conceptual and methodological considerations”, availableat:wwwunix.oit.umass.edu/,aizen/pdf/tpb.measurement.pdf (accessed 9 June 2004).

Ajzen, I. 1991. The Theory of Planned Behavior, Organizational Behavior and Human Decision Processes, vol. 50, no. 2, pp. 179-211.

Aulia, NH, 2007, "Center for Innovation", Entrepreneurship dan Leadership, Sekolah Bisnis dan Manajemen, ITB.

Aldrich, H., dan C. Zimmer, 1986. “Entrepreneurship through Social Network', in D. L. Sexton and R. W. Smilor (eds. ”.) The Art and Science of Entrepreneurship, Cambridge: Ballinger Publishing, 3-25.

Bandura, A., 1977. Social Learning Theory, Englewood Cliffs, New Jersey: Prentice Hall.

Bock, G.W. and Kim, Y.G. 2002. "Breaking the myths of rewards An Exploratory Study of Attitudes About Knowledge Sharing", Information Resources Management Journal; Apr-Jun, ABI/INFORM Global pg. 14

Buchori, M. 1982. Psikologi Pendidikan. Bandung: Jemars

Choo, S., dan M. Wong, 2006. "Entrepreneurial intention: triggers and barriers to new venture creations in Singapore". Singapore Management Review 28 (2): 47-64.

Cromie, S., 2000. "Assessing entrepreneurial inclinations: some approaches and business start-ups". International Journal of Entrepreneurial Behaviour and Research 5 (2): 48-63.

Duh, M., 2003. "Family enterprises as an important factor of the economic development: the case of Slovenia". Journal of Enterprising Culture 11 (2): 111-130.

Giles, M., dan A. Rea, 1970. "Career self-efficacy: an application of the theory of planned behavior". Journal of Occupational \& Organizational Psychology 73 (3):393-399

Ghozali, Imam. 2008 , Aplikasi Analisis Multivariate, Badan Penerbit Universitas Diponegoro.

Global Entrepreneurship Monitor. http://www.gemconsortium.org/ 2010. Global Entrepreneurship Monitor Special Report. http://www.gemconsortium.org/

Hacket, G. dan N. E. Betz, 1986. "Application of self-efficacy theory to understanding career choice behavior". Journal of Social Clinical and Phsycology 4: 279-289.

Indarti, N., 2004. "Factors affecting entrepreneurial intentions among Indonesian". Jurnal Ekonomi dan Bisnis 19 (1): 57-70.

Indarti dan Rostiani, 2008. "Intensi Kewirausahaan Mahasiswa: Studi Perbandingan antara Indonesia, Jepang dan Norwegia”, Jurnal Ekonomika dan Bisnis Indonesia, Vol 23, Universitas Gajah Mada.

I Dewa Ayu Made Budhyani, 2003, "Niat untuk berwiraswasta pada kalangan remaja siswa sekolah menengah kejuruan negeri di Provinsi Bali”, Jurnal Pendidikan dan pengajaran IKIP Singaraja, No 3 th XXXVI juli 2003, issn 02158250

Katz, J., dan W. Gartner, 1988. "Properties of emerging organizations". Academy of Management Review 13 (3): 429-441.

Kolvereid, L., 1996. "Prediction of employment status choice intentions". Entrepreneurship Theory and Practice 21 (1): 47-57.

Kourilsky, M. L. dan W. B. Walstad, 1998. "Entrepreneurship and female youth: knowledge, attitude, gender differences, and educational practices". Journal of Business Venturing 13 (1): 77-88.

Kristiansen, S., 2001. "Promoting African pioneers in business: what makes a context conducive to smallscale entrepreneurship?". Journal of Entrepreneurship 10 (1): 43-69.

Kristiansen, S, 2002. "Individual perception of business contexts: the case of small-scale entrepreneurs in Tanzania”. Journal of Developmental Entrepreneurship 7 (3).

Krueger, N. F. dan A. L. Carsrud, 1993. "Entrepreneurial intentions: applying the theory of planned behavior". Entrepreneurship \& Regional Development 5 (4): 315-330.

Lee, J., 1997. "The motivation of women entrepreneurs in Singapore". International Journal of Entrepreneurial Behaviour and Research 3 (2): 93-110. 
Mazzarol, T., T. Volery, N. Doss, dan V. Thein, 1999. "Factors influencing small business start ups", International Journal of Entrepreneurial Behaviour and Research 5 (2):48-63

McClelland, D., 1961. The Achieving Society, Princeton, New Jersey: Nostrand.

McClelland, D., 1971. "The Achievement Motive in Economic Growth, in: P. Kilby (ed.)". Entrepreneurship and Economic Development, New York The Free Press, 109-123.

Marsden, K., 1992. "African entrepreneurs - pioneer of development". Small Enterprise Development 3 (2): $15-25$.

Mead, D. C. dan C. Liedholm, 1998. "The dynamics of micro and small enterprise in developing countries". World Development 26 (1): 61-74.

Meier, R. dan M. Pilgrim, 1994. "Policy-induced constraints on small enterprise development in Asian developing countries". Small Enterprise Development 5 (2): 66-78.

Remenyi, D., B. Williams, A. Money, dan E. Swartz, 2000. Doing Research in Business and Management: An Introduction to Process and Method. London: Sage Publications.

Scapinello, K. F., 1989. "Enhancing differences in the achievement attributions of high and low motivation groups". Journal of Social Psychology 129 (3): 357-363.

Schiller, B.R., dan P. E. Crewson, 1997. "Entrepreneurial origins: a longitudinal inquiry". Economic Inquiry 35 (3): 523-531.

Sengupta, S. K. dan S. K. Debnath, 1994. "Need for achievement and entrepreneurial success: a study of entrepreneurs in two rural industries in West Bengal". The Journal of Entrepreneurship 3 (2): 191204.

Singh, K.A., dan K. V. S. M. Krishna, 1994. "Agricultural entrepreneurship: the concept and evidence". Journal of Entrepreneurship 3 (1): 97-111.

Sinha, T. N., 1996. "Human factors in entrepreneurship effectiveness". Journal of Entrepreneurship 5 (1): 23-29.

Swierczek, F. W., dan T. T. Ha, 2003. "Entrepreneurial orientation, uncertainty avoidance and firm performance: an analysis of Thai and Vietnamese SMEs". International Journal of Entrepreneurship and Innovation 4 (1): 46-58.

Tkachev, A., dan L. Kolvereid, 1999. "Self-employment intentions among Russian students". Entrepreneurship \& Regional Development 11: 269-280.

Werner, P. 2004. "Reasoned Action and Planned Behavior, in S.J. Peterson and T.S. Bredow (eds)", Middle range Theories: Application to Nursing Research, Lippincott Williams and Wilkins, Philadelphia, pp. 125-147.

Zimmerer, W. Thomas, Norman M Scarborough, 1996, Entrepreneurship and the new venture Formation, New Jersey. 